\title{
Crop residue, manure and fertilizer in dryland maize under reduced tillage in northern China: I grain yields and nutrient use efficiencies
}

\author{
Xiaobin Wang $\cdot$ Dianxiong Cai · \\ Willem B. Hoogmoed · Udo D. Perdok • \\ Oene Oenema
}

Received: 29 June 2006/ Accepted: 18 May 2007/Published online: 14 July 2007

(C) Springer Science+Business Media B.V. 2007

\begin{abstract}
The rapidly increasing population and associated quest for food and feed in China has led to increased soil cultivation and nitrogen $(\mathrm{N})$ fertilizer use, and as a consequence to increased wind erosion and unbalanced crop nutrition. In the study presented here, we explored the long-term effects of various combinations of maize stover, cattle manure and nitrogen $(\mathrm{N})$ and phosphorus $(\mathrm{P})$ fertilizer applications on maize (Zea mays L.) yield and nutrient and water use efficiencies under reduced tillage practices. In a companion paper, we present the effects on nutrient balances and soil fertility characteristics. The ongoing factorial field trial was conducted at Shouyang Dryland Farming Experimental Station in northern China from 1993 onwards. The incomplete, determinant-optimal design comprised 12 treatments,
\end{abstract}

X. Wang $(\bowtie) \cdot$ D. Cai

Institute of Agricultural Resources and Regional

Planning, Chinese Academy of Agricultural Sciences and

Ministry of Agriculture Key Laboratory of Plant Nutrition

and Nutrient Cycling, 12 Zhongguancun Nandajie,

Beijing 100081, China

e-mails: xiaobin.wang@wur.nl; xbwang@caas.ac.cn

X. Wang · W. B. Hoogmoed · U. D. Perdok

Farm Technology Group, Wageningen University, P.O. Box 43, Wageningen 6700 AA, The Netherlands

O. Oenema

Environmental Sciences, Wageningen University, P.O. Box 8005, Wageningen 6700 EC, The Netherlands including a control treatment, in duplicate. Grain yields and $\mathrm{N}, \mathrm{P}$, and potassium $(\mathrm{K})$ uptakes and $\mathrm{N}, \mathrm{P}$ and $\mathrm{K}$ use efficiencies were greatly influenced by the amount of rain during the growing season (GSR), and by soil water at sowing (SWS). There were highly significant interactions between GSR and added stover and manure, expressed in complex annual variations in grain yield and $\mathrm{N}, \mathrm{P}$ and $\mathrm{K}$ use efficiencies. Annual mean grain yields ranged from $3,000 \mathrm{~kg} \mathrm{ha}^{-1}$ to $10,000 \mathrm{~kg} \mathrm{ha}^{-1}$ and treatment mean yields from $4,500 \mathrm{~kg} \mathrm{ha}^{-1}$ to $7,000 \mathrm{~kg} \mathrm{ha}^{-1}$. Balanced combination of stover $(3,000-6,000 \mathrm{~kg})$, manure $(1,500-6,000 \mathrm{~kg})$ and $\mathrm{N}$ fertilizer $(105 \mathrm{~kg})$ gave the highest yield. Stover and manure were important for supplying $\mathrm{K}$, but the effects differed greatly between years. Overall mean $\mathrm{N}$ recovery efficiency (NRE) ranged from $28 \%$ to $54 \%$, depending on $\mathrm{N}$ source. NRE in wet years ranged from $50 \%$ to $90 \%$. In conclusion, balanced combinations of stover, manure and NP fertilizer gave the highest yield and NRE. Reduced tillage with adding stover and manure in autumn prior to ploughing is effective in minimizing labor requirement and wind erosion. The potentials of split applications of $\mathrm{N}$ fertilizer, targeted to the need of the growing crop (response farming), should be explored to further increase the $\mathrm{N}$ use efficiency.

Keywords Crop residue - Dryland · Fertilizer . Maize · Manure · Nitrogen · Nutrient management · Nutrient use efficiency · Phosphorus · Potassium . Water use efficiency 


\section{Introduction}

Fertilizer nitrogen $(\mathrm{N})$ and phosphorus $(\mathrm{P})$ uses have increased rapidly in China during the last two decades, in response to the increasing quest for food by the rapidly growing human population. On the lists of fertilizer production and consumption, China ranks number one, accounting for $22 \%$ and $25 \%$ of the world totals, respectively (FAO 2005). From the 1980s onwards, the rate of increase of fertilizer use has been larger than the rate of increase of food production, and the gap between the growth rates has continued to widen (Ye and Rozelle 1994). Fertilizer costs account for about $25 \%$ of the total annual expenses in crop production and for about $50 \%$ of total cost for input materials (seed, fertilizer, pesticides, machinery, irrigation), even though fertilizers are heavily subsidized (Lin et al. 1999; Ye and Rozelle 1994). The increasing use of $\mathrm{N}$ and $\mathrm{P}$ fertilizers and the neglect of manure and wastes as valuable resources of nutrients and soil organic matter (Ju et al. 2005; Yang 2006) have contributed to unbalanced fertilization, low fertilizer use efficiency, and to eutrophication of surface waters and contamination of the environment (Cao 1996; Cai et al. 2002; Bao et al. 2006; Ju et al. 2006).

The dryland areas of northern China are highly important for providing food and feed to the growing human and animal populations. Continuous maize (Zea mays L.) or wheat (Triticum aestivum L.), and wheat-maize rotations are the dominant cropping systems. Maize accounts for $22 \%$ of the total area of food crops, and $26 \%$ of the total food production in China (China Agricultural Yearbook 1999). Yields of maize and wheat vary greatly from year to year, mainly because of the variable (unpredictable) rainfall and wind erosion in spring (Wang et al. 2006). These effects are exaggerated by the current practices of removing crop residues from the field after harvest, to leave the ploughed soil bare during winter, and to plough the soil again in spring after fertilizer application. These practices commonly lead to soil drying and severe wind erosion in early spring. Erosion of fertile top soil, removal of crop residues (to feed animals and to be used as fuel for cooking with only partial return of manure and ashes to the cropped land) and burning of crop residues have led to nutrient depleted soils on various places (Rees et al. 1997; Cai et al. 2002; Peng et al. 2006).
Soil conservation and improved nutrient management practices are gaining interest of Chinese research and policy communities (Wang et al. 1999, 2001, 2003; Ju et al. 2005). There is a revival of the centuries-long tradition of recycling organic residues, but now combined with mineral fertilizers. For the humid areas of China, effects of combined applications of animal manure and inorganic fertilizers on soil fertility and crop yield have been reported by Lin and Lin (1985), Xie et al. (1987), and Liu et al. (1996). Long-term effects of combined applications of animal manure and mineral fertilizers in dryland areas have been examined by Fan et al. (2005a), Yang et al. (2004), and Zhen et al. (2006). A step further is to combine conservation tillage with improved nutrient management practices, including also the recycling of crop residues, because increasing amounts of crop residues are left in the field, especially in areas where fossil energy is used for cooking.

Reduced tillage was introduced in the study area in the early 1990s and it showed to be highly effective in decreasing soil drying and wind erosion (Wang et al. 2006). However, this practice required that fertilizers, crop residues and manure are applied in autumn prior to ploughing, approximately 6 months before maize is seeded. Applying fertilizers long before the crop growing season is only feasible in dry conditions where nutrient losses are minimal. The objective of our study is to optimize the combined application of NP fertilizers, maize stover and cattle manure under reduced tillage practices. We therefore assessed the long-term effects of these applications on maize grain yield and nutrient use efficiency. A companion paper (Wang et al. 2007) describes the effects of these combined applications on N, P and K balances, soil organic matter dynamics and soil fertility indices.

\section{Materials and methods}

Site description

The ongoing long-term field experiment started in 1992 at the Dryland Farming Experimental Station (Ministry of Agriculture) in Shouyang, Shanxi province in northern China $\left(112^{\circ}-113^{\circ} \mathrm{E}, 37^{\circ}-38^{\circ} \mathrm{N}\right)$. The 
area has a mean altitude of $1,100 \mathrm{~m}$ above sea level and a continental monsoon climate with an average annual rainfall of $520 \mathrm{~mm}$. Severe water and wind erosion in the past has led to the formation of a hilly landscape. The winter and spring season are dry and there are often strong winds. The dominant cropping system is continuous spring maize, which accounts for over $50 \%$ of the total area for crop production. Spring drought often is a limiting factor for seed germination and the emergence and growth of spring maize.

The experimental site has a sandy loam cinnamon soil, classified as a Calcaric-Fluvic Cambisol (ISS-CAS 2003; IUSS 2006). At the start of the experiment in 1992, soil pH was 7.9, and organic matter and $\mathrm{N}$ contents were 25.7 and $1.04 \mathrm{~g} \mathrm{~kg}^{-1}$, respectively. Soil fertility level was low to medium, judged on the basis of P-Olsen (7.3 $\mathrm{mg} \mathrm{P} \mathrm{kg}^{-1}$ ) and $\mathrm{NH}_{4} \mathrm{OAc}$ extractable $\mathrm{K}\left(2.2 \mathrm{mmol} \mathrm{K} \mathrm{kg}{ }^{-1}\right)$ in the top $20 \mathrm{~cm}$ soil. To make the soil mineral $\mathrm{N}$ status spatially uniform and low, millet was grown without nutrient application in 1992, before the actual start of the experiment.

\section{Experimental design}

The experimental layout was a determinant-optimal (Xu 1988) 311A hybrid design, applying the response surface methodology (Roquemore 1976) with three factors, viz. NP fertilizer, maize stover and cattle manure. The experiment comprises 12 treatments, including a control treatment, in duplicate. Fertilizer $\mathrm{NP}$ (ratio N:P = 1:0.44) applications were 0, 31, 105, 179 and $210 \mathrm{~kg} \mathrm{ha}^{-1}$. Maize stover applications were $0,879,3,000,5,121$ and $6,000 \mathrm{~kg} \mathrm{ha}^{-1}$. Cattle manure applications were $0,1,500,3,000,4,500$ and $6,000 \mathrm{~kg} \mathrm{ha}^{-1}$. This experimental design allows the use of a minimal set of factors of the variancecovariance matrix and provides a maximal efficiency of the experiment. An important condition is that within the range of applications chosen, the optimum responses are found. The procedures of this design are explained in Khuri and Cornell (1987) and shown in Table 1. The corresponding statistical model is a quadratic equation of the form:

$$
\begin{aligned}
Y= & b_{0}+b_{1} X_{1}+b_{2} X_{2}+b_{3} X_{3}+b_{12} X_{1} X_{2} \\
& +b_{13} X_{1} X_{3}+b_{23} X_{2} X_{3}+b_{11} X_{1}^{2}+b_{22} X_{2}^{2}+b_{33} X_{3}^{2}
\end{aligned}
$$

where $\mathrm{Y}=$ grain yield or nutrient uptake, in $\mathrm{kg} \mathrm{ha}^{-1}$; $\mathrm{X}_{1}=\mathrm{NP}$ fertilizer, $\mathrm{kg} \mathrm{ha}{ }^{-1} ; \mathrm{X}_{2}=$ stover, $\mathrm{kg} \mathrm{ha}^{-1}$; $\mathrm{X}_{3}=$ manure, $\mathrm{kg} \mathrm{ha}{ }^{-1}$; and $\mathrm{b}_{0}, \mathrm{~b}_{1}, \mathrm{~b}_{2}, \mathrm{~b}_{3}, \mathrm{~b}_{11}, \mathrm{~b}_{12}, \mathrm{~b}_{22}$, $b_{13}, b_{23}, b_{33}=$ coefficients.

Methods

Plots $\left(6 \times 6 \mathrm{~m}^{2}\right)$ were laid down randomly in duplicate. Locally recommended maize varieties were used, i.e., Yandan No.12 in 1993-1997, Shandannong No.1 in 1998, and Jindan No.34 in 19992004. The $\mathrm{N}$ and $\mathrm{P}$ fertilizers were urea $(46 \% \mathrm{~N})$ and superphosphate $(7 \% \mathrm{P})$ in a ratio of $\mathrm{N}$ to $\mathrm{P}$ of 1:0.44. Maize stover and cattle manure were obtained from local farms. The weighted mean contents of organic matter, total $\mathrm{N}$, total $\mathrm{P}$ (as $\mathrm{P}$ ) and total $\mathrm{K}$ were $75 \%$, $0.63 \%, 0.039 \%$ and $0.72 \%$ for maize stover (ratio of $\mathrm{N}: \mathrm{P}: \mathrm{K}=100: 6: 114)$ and $36 \%, 0.96 \%, 0.17 \%$ and $0.74 \%$ for cattle manure (ratio of $\mathrm{N}: \mathrm{P}: \mathrm{K}=100: 18: 77$ ), respectively. Maize stover (s), cattle manure (m) and fertilizers (f) were broadcast and incorporated into the soil after maize harvest in the fall by ploughing (20 cm deep). Seeding was done in spring, usually at the end of April, without any tillage. Maize was seeded in rows at distances of $60 \mathrm{~cm}$ between rows and at $30 \mathrm{~cm}$ within the rows. Mean plant density was 55,555 per ha. Weeding was done manually twice during the growing season. Maize was harvested close to the ground using sickles and all harvested biomass was removed from the plots, usually in October. Grain yield and crop residues (rachis + stems + leaves + husks) were determined by harvesting the center $1.8 \times 2.1 \mathrm{~m}^{2}$ of the plots. Samples of grain and crop residues were oven dried at $70^{\circ} \mathrm{C}$ and weighed. Harvest index (HI) was calculated as the ratio of grain to total aboveground biomass yield.

Grain and stover were analyzed for total $\mathrm{N}$ using the Kjeldahl method, total $\mathrm{P}$ using the $\mathrm{H}_{2} \mathrm{SO}_{4}-\mathrm{HClO}_{4}$ method and total $\mathrm{K}$ using the $\mathrm{HNO}_{3}-\mathrm{HClO}_{4}$-flame photometry methods (Westerman 1990). Plant analyses of N and P started in 1993, those of K in 1997. Soil samples for moisture determination were taken at seeding and after harvest per plot. Each sample was a composite of three random $2-\mathrm{cm}$ diameter cores per plot, taken at depths of 0-10, 10-20, 20-40, 40-60, 60-80, 80-100, 100-120, 120-140, 140-160, 160$180,180-200 \mathrm{~cm}$. The total volume of soil per layer 


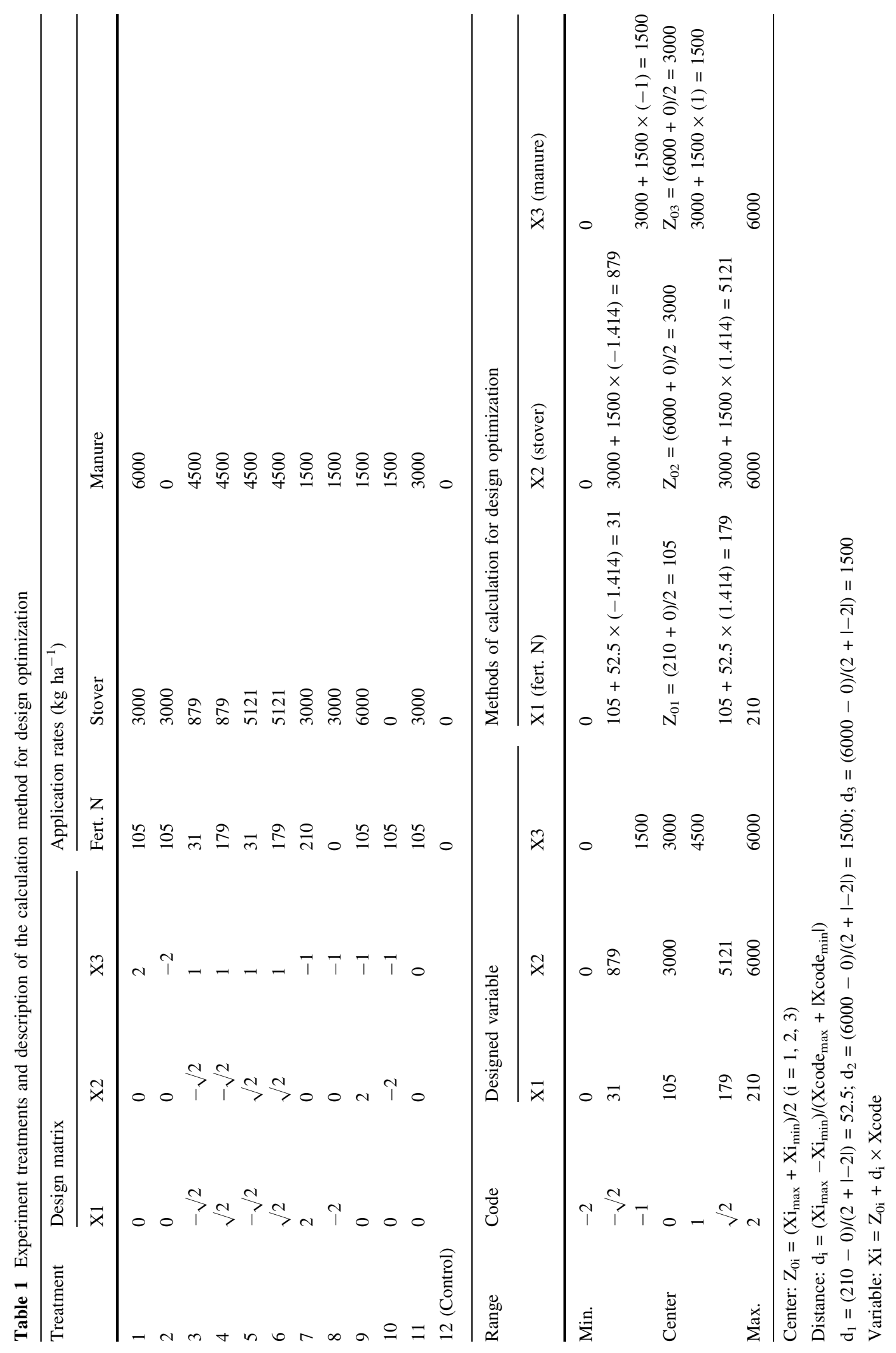


was mixed thoroughly, and subsamples were weighed before and after drying at $105^{\circ} \mathrm{C}$.

Data processing and statistical analysis

Three indices for nutrient use efficiency were chosen, i.e. the additional grain yield per unit of added nutrient (agronomic efficiency, AE), the ratio of grain yield to aboveground nutrient uptake (internal utilization efficiency or physiological efficiency, PhE) and the apparent recovery efficiency (RE) of applied inputs (Novoa and Loomis 1981; Moll et al. 1982). $\mathrm{AE}$ was calculated as the increase in grain yield that resulted from added nutrients relative to the control treatment, in $\mathrm{kg}$ grain per $\mathrm{kg} \mathrm{N}$ or $\mathrm{P}$ applied via fertilizer, stover and manure. The apparent recovery efficiency of applied N (NRE) or P (PRE) is defined as the percentage of added $\mathrm{N}$ or $\mathrm{P}$ that is recovered in aboveground plant biomass at the end of the cropping season. For N, the equations for $\mathrm{AE}, \mathrm{RE}$ and $\mathrm{PhE}$ read as follows.

$$
\begin{aligned}
& \mathrm{AE}=\left(\mathrm{GY}_{\mathrm{i}}-\mathrm{GY}_{\mathrm{ck}}\right) /(\mathrm{Nf}+\mathrm{Ns}+\mathrm{Nm})_{\mathrm{i}} \\
& \mathrm{RE}=100 *(\text { Nuptake_i }- \text { Nuptake_ck }) / \\
& (\mathrm{Nf}+\mathrm{Ns}+\mathrm{Nm}) \_\mathrm{i}
\end{aligned}
$$

$\mathrm{PhE}=\mathrm{GY} /$ Nuptake

where $\mathrm{GY}_{\mathrm{i}}=$ grain yield of treatment $\mathrm{i}$, with $\mathrm{i}=1-11$, $\mathrm{kg} \mathrm{ha}^{-1} ; \mathrm{GY}_{\mathrm{ck}}=$ grain yield of the control treatment (treatment 12), $\mathrm{kg} \mathrm{ha}^{-1}$; Nuptake $_{\mathrm{i}}=$ the $\mathrm{N}$-uptake of treatment $\mathrm{i}, \mathrm{kg} \mathrm{ha}^{-1}$; Nuptake $_{\mathrm{ck}}=\mathrm{N}$-uptake of the control treatment, $\mathrm{kg} \mathrm{ha}^{-1} ; \mathrm{Nf}_{\mathrm{i}}=$ fertilizer $\mathrm{N}$ application of treatment $\mathrm{i}, \mathrm{kg} \mathrm{ha}^{-1} ; \mathrm{Ns}_{\mathrm{i}}=$ amount of $\mathrm{N}$ in stover applied to treatment $\mathrm{i}, \mathrm{kg} \mathrm{ha}^{-1} ; \mathrm{Nm}_{\mathrm{i}}=$ amount of $\mathrm{N}$ in manure applied to treatment $\mathrm{i}, \mathrm{kg} \mathrm{ha}^{-1}$.

Apparent water use or apparent evapotranspiration (ET, in $\mathrm{mm}$ ) was calculated from the change in soil water contents between the beginning of the growing season at seeding (SWS, in $\mathrm{mm}$ ) and the end of the growing season at crop harvest (SWH, in $\mathrm{mm}$ ) plus rainfall received during the growing season (GSR), viz.

$\mathrm{ET}=(\mathrm{SWS}-\mathrm{SWH})+\mathrm{GSR}$

Hence, we assumed that there were no losses via deep drainage and runoff during the growing season. Apparent water use efficiency (WUE, in $\mathrm{kg} \mathrm{ha}^{-1} \mathrm{~mm}^{-1}$ ) was calculated from GY and ET, according to.

$\mathrm{WUE}=\mathrm{GY} / \mathrm{ET}$

Statistical analyses were done using GLM, REG and RSREG procedures of the SAS Institute, Inc. (2004). The data were subjected to an analysis of variance using. the GLM procedure. The mean pairwise comparison was based on the DUNCAN test at the 0.05 probability level (at $P \leq 0.05$ ). Mean responses of grain yield (GY) and N, P and K uptakes to added NP fertilizer, maize stover and cattle manure were calculated using Eq. 1. In addition, stepwise multivariate regression analyses were carried out. Linear and nonlinear (parabolic) statistical models were fitted to describe the relationships between GY and nutrient uptake on the one hand and added nutrients via fertilizer, crop residues and manure applications and GSR and SWS on the other hand.

\section{Results}

Variation in rainfall and soil water

During the 12-year experimental period (1993-2004), annual rainfall ranged from $251 \mathrm{~mm}$ in the dry year 1997 to $675 \mathrm{~mm}$ in the wet year 1995. On average, rainfall during the growing season (GSR) accounted for $89 \%$ of the annual rainfall, indicating that the growing season for maize (May-October) is well

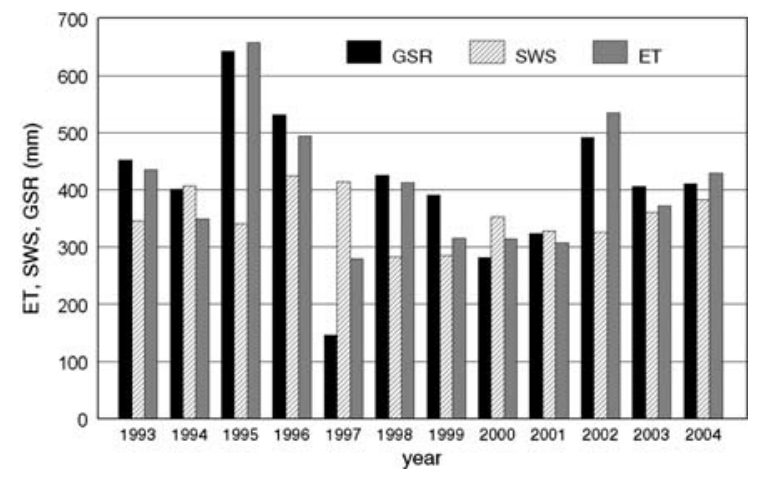

Fig. 1 Annual growing season rainfall (GSR), average amounts of soil water in the upper $2 \mathrm{~m}$ at sowing (SWS), and apparent water use (ET), in Shouyang during the experimental period 1993-2004 
synchronized to the rainy season (June-September). However, annual variations in GSR were large, ranging from $146 \mathrm{~mm}$ in 1997 to $642 \mathrm{~mm}$ in 1995 (Fig. 1), and soil water shortage at sowing due to spring drought often occurred. Dry conditions at seeding impede seedling emergence and generally lead to low grain yield and nutrient uptake by maize (Cai et al. 1994). Apparent water use (ET) by maize ranged from a mean of $280 \mathrm{~mm}$ in 1997 to a mean of $660 \mathrm{~mm}$ in 1995 (Fig. 1).

Mean grain yield and N, P and K uptake

Mean grain yield and $\mathrm{N}, \mathrm{P}$ and $\mathrm{K}$ uptakes in aboveground biomass per treatment are shown in Table 2. Note that treatments are in the order of increasing GY. The control (treatment 12) had the lowest $\mathrm{GY}$ and $\mathrm{N}, \mathrm{P}$ and $\mathrm{K}$ uptakes, and treatment 9 (with $\mathrm{f}=105, \mathrm{~s}=6,000$, and $\mathrm{m}=1,500 \mathrm{~kg} \mathrm{ha}^{-1}$ ) the highest $\mathrm{GY}$ and also the highest $\mathrm{N}, \mathrm{P}$ and $\mathrm{K}$ uptakes. Clearly, balanced combinations of NP fertilizer, stover and manure gave the highest mean yield, and the slight differences in GY between treatments 6,11 , 1 and 9 (the four treatments at the bottom of Table 2) were not statistically significant. Doubling NP fertilizer applications and halving the stover application (comparison of treatments 7 and 9) gave statistically significant lowering of GY, suggesting above optimal $\mathrm{N}$ application and below optimal $\mathrm{K}$ application in treatment 7 (see below).

Calculated mean responses of GY and N, P and K uptakes according to the regression equation pertinent to the design of the experiment (Eq. 1) are shown in Fig. 2. The regression coefficients for linear and quadratic effects of added NP fertilizer were all highly significant, but the mean effects of added manure and stover were not statistically significant (not shown). There were also no statistically significant interactions between added NP fertilizer, stover and manure in mean GY and $\mathrm{N}, \mathrm{P}$ and $\mathrm{K}$ uptakes when using Eq. 1. Figure 2 shows that added stover and manure had larger relative effects on $\mathrm{K}$ uptake than on $\mathrm{GY}$ and $\mathrm{N}$ and $\mathrm{P}$ uptakes. Also, maximum $\mathrm{K}$ uptake was obtained at NP fertilizer application rates of about $100 \mathrm{~kg}$ per ha, while maximum GY and $\mathrm{N}$ and $\mathrm{P}$ uptakes were obtained at NP fertilizer application rates of 150-200 kg per ha, when no stover and/or manure was applied. When combined with stover and manure, the required amounts of NP fertilizer for reaching maximum $\mathrm{K}$ uptake were larger than in the case of using only NP fertilizer. Conversely, the required amounts of NP fertilizer for obtaining maximum $\mathrm{GY}$ and $\mathrm{N}$ and $\mathrm{P}$ uptakes were smaller than in the case of single applications of NP fertilizer. These results indicate that the soil was responsive to $\mathrm{N}, \mathrm{P}$ and $\mathrm{K}$ applications; a response to $\mathrm{K}$ was not foreseen at the start of the experiment.

Mean harvest index (HI) ranged from $47 \%$ to $52 \%$, with highest values at intermediate GY (Table 2). Mean $\mathrm{N}$ recovery efficiency (NRE) in aboveground biomass ranged from $28 \%$ to $54 \%$, and apparent $\mathrm{N}$ recovery in the grain (GNRE) from $18 \%$ to $35 \%$. Variations between years within treatments were relatively large and only few treatments had statistically significant differences in NRE and GNRE. Mean $\mathrm{P}$ recovery efficiency (PRE) in aboveground biomass ranged from $10 \%$ to $85 \%$, and GPRE from $8 \%$ to $62 \%$. Highest NRE and PRE were in treatment 8 with combined applications of stover and manure, but without added NP fertilizer.

Mean apparent water use (ET) did not vary much among treatments (range $400-425 \mathrm{~mm}$ ), and as a consequence, water use efficiency (WUE) varied greatly between treatments (Table 2). Lowest WUE (11 $\mathrm{kg}$ per ha per $\mathrm{mm}$ available water, or $1.1 \mathrm{~kg} \mathrm{ha}^{-1} \mathrm{~m}^{-3}$ ) was found in the control treatment and the highest WUE (19 $\mathrm{kg}$ per ha per mm available water, or $1.9 \mathrm{~kg} \mathrm{ha}^{-1} \mathrm{~m}^{-3}$ ) in treatment 9 . This range (1.1-1.9 $\left.\mathrm{kg} \mathrm{ha}^{-1} \mathrm{~m}^{-3}\right)$ is similar to the range $(1.1-$ $2.0 \mathrm{~kg} \mathrm{ha}^{-1} \mathrm{~m}^{-3}$ ) measured in a long-term maize field experiment with various fertilization treatments in Gansu in China (Fan et al. 2005a).

Annual variations in grain yields

Annual variations in grain yield were large, ranging from about 3,000 in the dry year 1999 to more than $10,000 \mathrm{~kg} \mathrm{ha}^{-1}$ in treatments with balanced fertilization in the wet years 1994, 1996 and 1998 (Fig. 3). Yields were related to GSR and also to soil water content at seeding (SWS). Grain yields in all treatments tended to decrease with time during the experimental period, especially in the control treatment (treatment 12). Differences in GY between the control treatment and the treatment with the second lowest GY (treatment 8 with $\mathrm{f}=0, \mathrm{~s}=3,000$, $\mathrm{m}=1,500 \mathrm{~kg} \mathrm{ha}^{-1}$ ) were absent during the first 


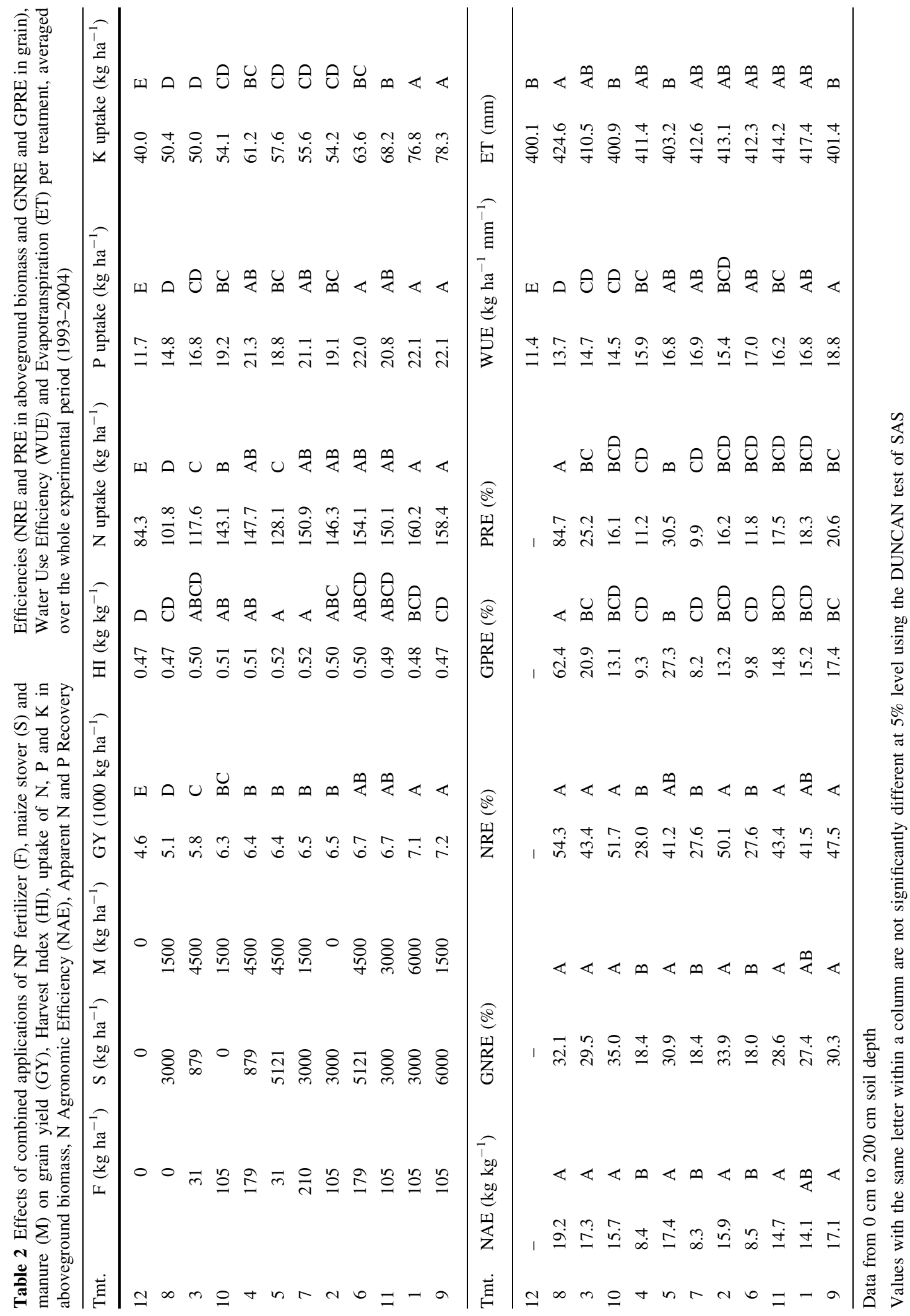


Fig. 2 Calculated average grain yield (GY), and plant $\mathrm{N}, \mathrm{P}$ and $\mathrm{K}$ uptake responses to NP fertilizer (F), with and without maize stover $\left(\mathrm{S}: \mathrm{kg} \mathrm{ha}^{-1}\right)$ or manure (M: $\mathrm{kg} \mathrm{ha}^{-1}$ ) inputs during the period of 19932004 using RSREG statistical models (Eq. 1): (a) GY, (b) N uptake, (c) P uptake, (d) K uptake (see text). Note that $Y$-axes do not start at zero
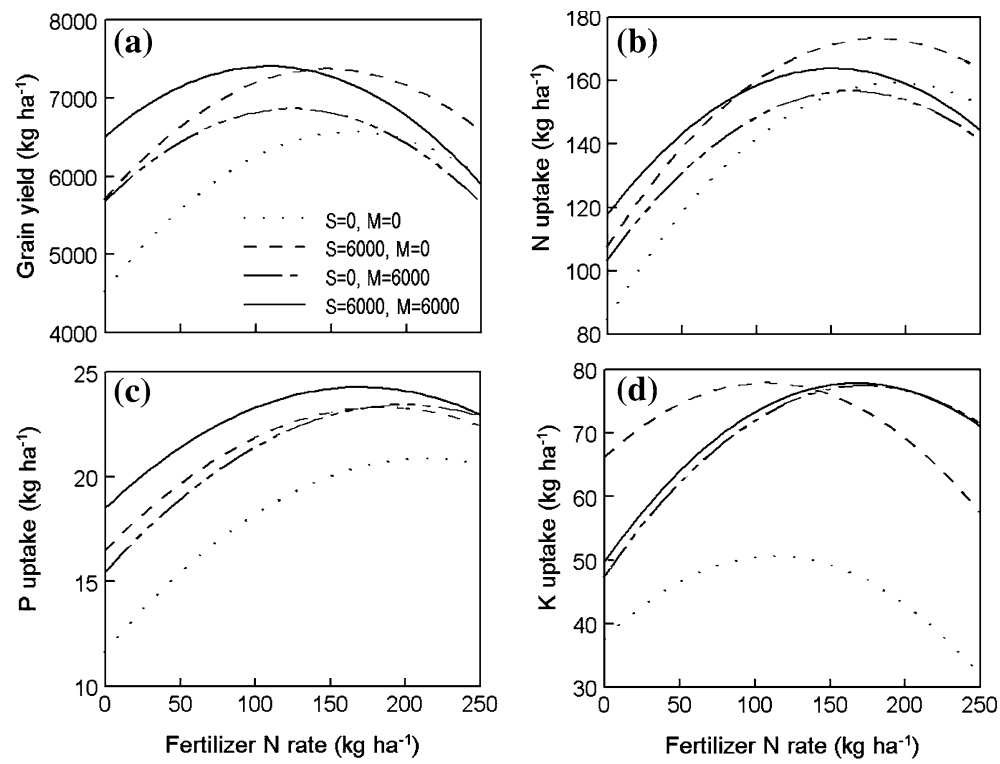

7 years (1993-1999), but were about 35\% during the last 5 years (2000-2004) of the experiment.

Statistical analyses indicated that annual variations in GY per treatment were related to added fertilizer, stover and manure, and especially to GSR and SWS. Grain yield appeared highly sensitive to rainfall in July (at tasseling). Highest percentage of explained variance in GY (up to 88\%) was obtained when the data set was split in wet $(93,94,95,96,98)$ and dry years $(97,99,00,01,02,03,04)$, and GY related to GSR and SWS, and added fertilizer, stover and manure. For dry years, GY was significantly related to SWS (but not to GSR) and to added fertilizer, stover and manure. In addition, there was a statistically significant interaction between added NP fertilizer and manure. For wet years, GY was significantly related to SWS and GSR (linearly and quadratic), and NP fertilizer, but not to added stover and manure (results not shown). These results would suggest that added manure and stover are important especially for dry years.

For the whole experimental period, differences in GY between treatments and between years were related to added fertilizer, stover and manure, and to SWS and the rainfall during the periods April-June, July and August-October (Fig. 3, Table 3). This model could also explain satisfactorily the decreasing trend in GY over the experimental period. Fan et al. (2005a, b) also observed decreasing trends in maize (and wheat) yields in a long-term field experiment, which they ascribed to changing soil properties, decreasing trends in GSR and their interactions. The similar trends in measured and calculated GY (Fig. 3) suggest that the decreasing trend in GY in our experiment is mainly related to the changes in rainfall during the periods April-June, July and AugustOctober. Overall, the statistical model tended to underestimate GY in wet years and overestimate GY in dry years. The large difference between measured and calculated GY in 2004 is possibly related to $\mathrm{N}$ losses prior and during the growing season and to diseases (head smut).

Water use efficiency (WUE) ranged from $4 \mathrm{~kg} \mathrm{ha}^{-1} \mathrm{~m}^{-3}$ (equivalent to $40 \mathrm{~kg} \mathrm{ha}^{-1} \mathrm{~mm}^{-1}$ of rainfall) in treatments with balanced nutrient inputs in dry 1997 to $0.65 \mathrm{~kg} \mathrm{ha}^{-1} \mathrm{~m}^{-3}\left(6.5 \mathrm{~kg} \mathrm{ha}^{-1} \mathrm{~mm}^{-1}\right.$ of rainfall) for the control treatments in wet 1999, 2002 and 2004 (Fig. 4). There was a factor 5 difference in apparent water use (ET) between extremely dry 1997 and extremely wet 1995, while GY differed by only a factor of 1-2. Conversely, similar ET in 1994 and 2004 (about $430 \mathrm{~mm}$ ) was accompanied with a factor 2-3 differences in GY. Evidently, there were additional factors involved in causing the large annual GY differences than simply GSR and SWS. The control treatments usually had the lowest WUE and treatments with balanced nutrient inputs the highest WUE in almost all years. 


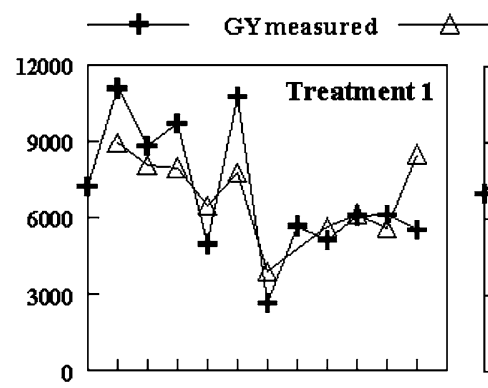

GY calculated
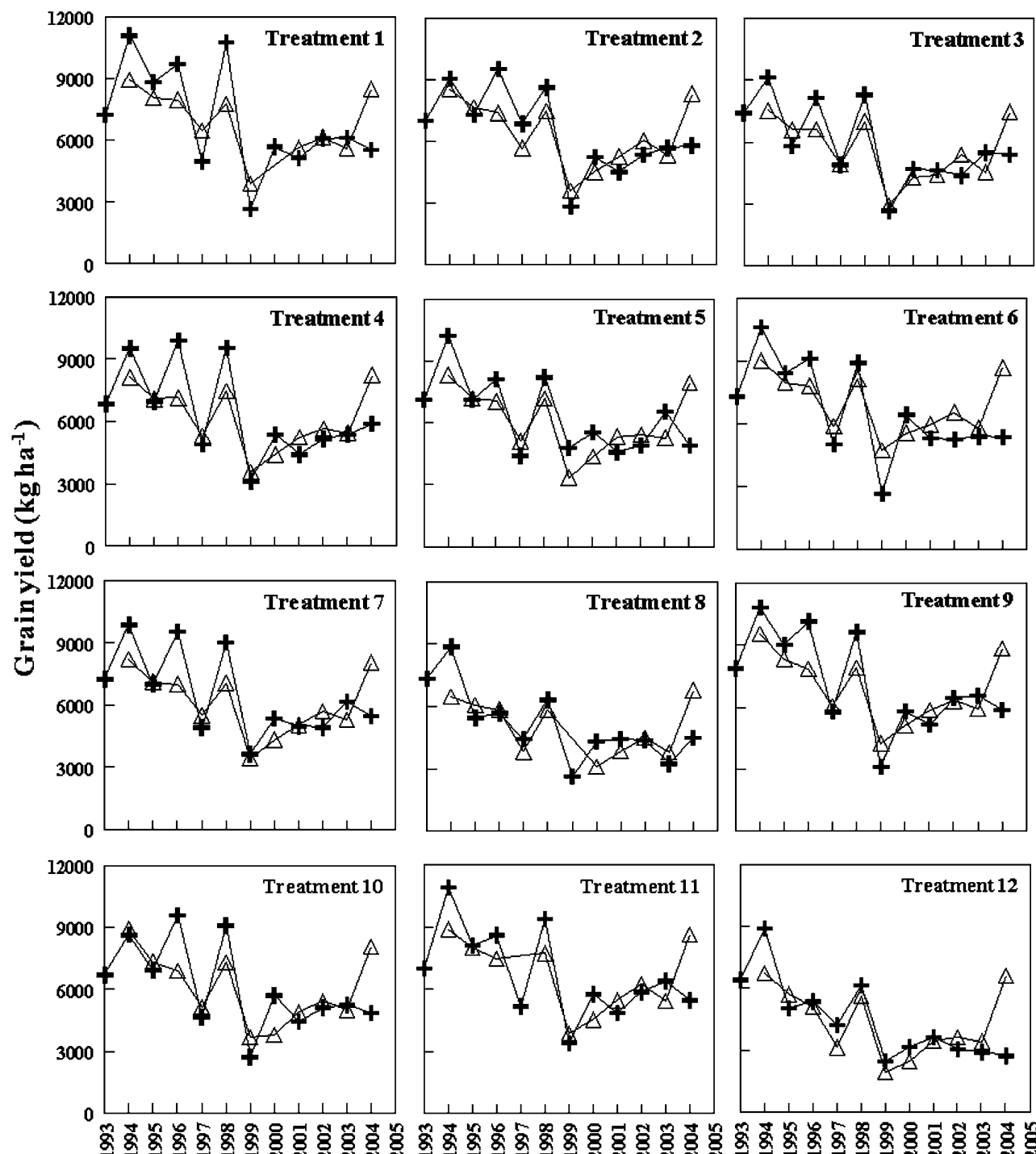

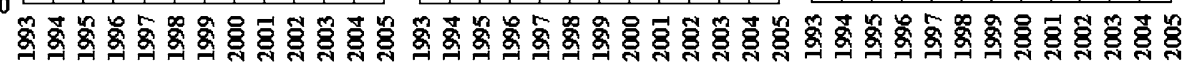

Fig. 3 Measured and calculated maize grain yields per treatment and year. Grain yields were calculated (GY-calculated) as function of added NP fertilizer (F), maize stover (S) and manure (M), and the amounts of soil water at seeding (SWS) and rainfall during the periods April-June (R(A-J)), July (R(J) and August-

Annual variations in $\mathrm{N}, \mathrm{P}$ and $\mathrm{K}$ uptakes in aboveground biomass

Uptake of $\mathrm{N}$ in aboveground biomass ranged from $100 \mathrm{~kg} \mathrm{ha}^{-1}$ to $190 \mathrm{~kg} \mathrm{ha}^{-1}$, with uptake in wet years nearly twice as high as those in dry years. Uptake of $\mathrm{N}$ was related to added fertilizer and stover, but not to added manure, and SWS and rainfall in July and
October (R(A-O), for the whole experimental period 1993-2004, according to $\mathrm{GY}=-5,140+24.9 \mathrm{~F}+0.14 \mathrm{~S}+0.07 \mathrm{M}+7.13$ $\mathrm{R}(\mathrm{A}-\mathrm{J})+23.5 \mathrm{R}(\mathrm{J})+3.17 \mathrm{R}(\mathrm{A}-\mathrm{O})+15.4 \mathrm{SWS}-0.09 \mathrm{~F}^{2}$ (see Table 3). Data from $0 \mathrm{~cm}$ to $200 \mathrm{~cm}$ soil depth. Yields for 1993 were not calculated because SWS data were missing

August-October (Table 3). Splitting the data set in dry and wet years (see above) resulted in a higher percentage variance accounted for, and gave statistically significant effects of added stover and manure in dry years, but not in wet years (not shown). In addition, there was a statistically significant interaction between added NP fertilizer and manure in dry years but not in wet years. 
Table 3 Coefficients of the regression models for grain yield (GY), N, P and K uptakes in aboveground biomass, and NRE, as function of NP fertilizer (both linear (Fertilizer) and quadratic (Fsq)), maize stover, and manure, soil water at sowing (SWS) and rainfall during the periods April-June $(\mathrm{R}(\mathrm{A}-\mathrm{J}))$, July $(\mathrm{R}(\mathrm{J}))$ and August-October $(\mathrm{R}(\mathrm{A}-\mathrm{O}))$, for the whole experimental period 1993-2004

\begin{tabular}{|c|c|c|c|c|c|c|c|c|c|c|}
\hline Dependent Variable & Param. $^{\mathrm{a}}$ & Intercept & Fertilizer & Stover & Manure & $\mathrm{R}(\mathrm{A}-\mathrm{J})$ & $\mathrm{R}(\mathrm{J})$ & $\mathrm{R}(\mathrm{A}-\mathrm{O})$ & SWS & Fsq \\
\hline GY & $\mathrm{PE}$ & -5140 & 24.9 & 0.14 & 0.07 & 7.13 & 23.5 & 3.17 & 15.4 & -0.09 \\
\hline$R^{2}=0.58$ & SE & 1213 & 6.4 & 0.07 & 0.07 & 3.39 & 2.71 & 1.47 & 2.80 & 0.03 \\
\hline \multirow[t]{2}{*}{$N=129$} & tValue & -4.24 & 3.9 & 2.01 & 1.0 & 2.1 & 8.70 & 2.16 & 5.51 & -3.02 \\
\hline & $\operatorname{Pr}>|t|$ & $<0.001$ & 0.001 & 0.047 & 0.32 & 0.04 & $<0.001$ & 0.03 & $<0.001$ & 0.003 \\
\hline $\mathrm{N}$ uptake & $\mathrm{PE}$ & -24.6 & 0.79 & 0.003 & 0.001 & -0.001 & 0.36 & 0.08 & 0.14 & -0.003 \\
\hline$R^{2}=0.48$ & SE & 26.6 & 0.14 & 0.001 & 0.002 & 0.07 & 0.06 & 0.03 & 0.06 & 0.001 \\
\hline \multirow[t]{2}{*}{$N=129$} & tValue & -0.93 & 5.68 & 1.75 & 0.91 & -0.02 & 6.12 & 2.49 & 2.29 & -3.95 \\
\hline & $\operatorname{Pr}>|t|$ & 0.36 & $<0.001$ & 0.08 & 0.36 & 0.99 & $<0.001$ & 0.01 & 0.02 & 0.001 \\
\hline P uptake & PE & -16.8 & 0.10 & 0.0005 & 0.000 & -0.05 & 0.11 & 0.01 & 0.05 & -0.0003 \\
\hline$R^{2}=0.58$ & SE & 4.54 & 0.02 & 0.000 & 0.000 & 0.01 & 0.01 & 0.006 & 0.01 & 0.000 \\
\hline \multirow[t]{2}{*}{$N=128$} & tValue & -3.69 & 4.06 & 1.83 & 1.57 & -4.15 & 10.6 & 2.59 & 5.16 & -2.67 \\
\hline & $\operatorname{Pr}>|\mathrm{t}|$ & 0.001 & $<0.001$ & 0.07 & 0.12 & $<0.001$ & $<0.001$ & 0.01 & $<0.001$ & 0.009 \\
\hline K uptake & $\mathrm{PE}$ & 5.46 & 0.29 & 0.002 & 0.001 & -0.04 & 0.30 & 0.04 & -0.003 & -0.001 \\
\hline$R^{2}=0.76$ & $\mathrm{SE}$ & 20.2 & 0.05 & 0.001 & 0.001 & 0.03 & 0.04 & 0.03 & 0.04 & 0.0003 \\
\hline \multirow[t]{2}{*}{$N=93$} & tValue & 0.27 & 5.37 & 4.11 & 2.05 & -1.29 & 8.59 & 1.01 & -0.08 & -4.72 \\
\hline & $\operatorname{Pr}>|\mathrm{t}|$ & 0.79 & $<0.001$ & $<0.001$ & 0.04 & 0.20 & $<0.001$ & 0.31 & 0.94 & $<0.001$ \\
\hline NRE & $\mathrm{PE}$ & 29.7 & 0.05 & -0.001 & -0.003 & 0.002 & 0.09 & 0.07 & 0.03 & -0.001 \\
\hline$R^{2}=0.21$ & $\mathrm{SE}$ & 19.6 & 0.11 & 0.001 & 0.001 & 0.05 & 0.04 & 0.02 & 0.04 & 0.000 \\
\hline \multirow[t]{2}{*}{$N=117$} & tValue & 1.52 & 0.44 & -0.92 & -2.40 & 0.04 & 2.02 & 2.97 & 0.74 & -1.72 \\
\hline & $\operatorname{Pr}>|t|$ & 0.13 & 0.66 & 0.36 & 0.018 & 0.97 & 0.045 & 0.004 & 0.46 & 0.089 \\
\hline
\end{tabular}

Data from $0 \mathrm{~cm}$ to $200 \mathrm{~cm}$ soil depth

${ }^{\text {a }} \mathrm{PE}=$ Parameter Estimate; $\mathrm{SE}=$ Standard Error; $\mathrm{Pr}=$ probability-value $(P$-value $)$

Uptake of $\mathrm{P}$ in aboveground biomass ranged from $8 \mathrm{~kg} \mathrm{ha}^{-1}$ to $32 \mathrm{~kg} \mathrm{ha}^{-1}$, with the highest values in wet years. Uptake of $\mathrm{P}$ was related to added fertilizer and stover, but not to added manure, and SWS and rainfall in April-June, July and August-October (Table 3). Again, splitting the data set in dry and wet years resulted in a higher percentage variance accounted for, and gave statistically significant effects of added stover and manure in dry years, but not in wet years (not shown). In addition, there was a statistically significant interaction between added NP fertilizer and manure in dry years but not in wet years.

Uptake of $\mathrm{K}$ in aboveground biomass ranged from $50 \mathrm{~kg} \mathrm{ha}^{-1}$ to $90 \mathrm{~kg} \mathrm{ha}^{-1}$, and was statistically significant related to added fertilizer, stover and manure, and to rainfall in July (Table 3 ). The positive effects of manure and stover on $\mathrm{K}$ uptake, suggests indeed that stover and manure were important for supplying K to maize. Percentage variance accounted for was much higher for $\mathrm{K}$ uptake than for $\mathrm{N}$ and $\mathrm{P}$ uptake, but it should be noted that $\mathrm{K}$ uptake was not determined in 1993-1996. Splitting the dataset in dry and wet years did not increase the percentage variance accounted for.

Relationships between GY and N, P and K uptakes are shown in Fig. 5. On average $40-50 \mathrm{~kg}$ of grain was produced per $\mathrm{kg} \mathrm{N}$ taken up in aboveground biomass (range 24-80). Highest $\mathrm{PhE}$ was in the control treatment and in productive years 1994, 1996, 1998, 2003. For N (Fig. 5a, b), PhE (GY/Nuptake) was relatively low in 1999 (about $30 \mathrm{~kg} \mathrm{~kg}^{-1}$ ). For P, $\mathrm{PhE}$ ranged from $160 \mathrm{~kg}$ in 1999 and 2004 to $800 \mathrm{~kg}$ in 2002. There were no clear patterns between treatments, indicating that climate had a much stronger effect than treatments on the $\mathrm{PPhE}$ 

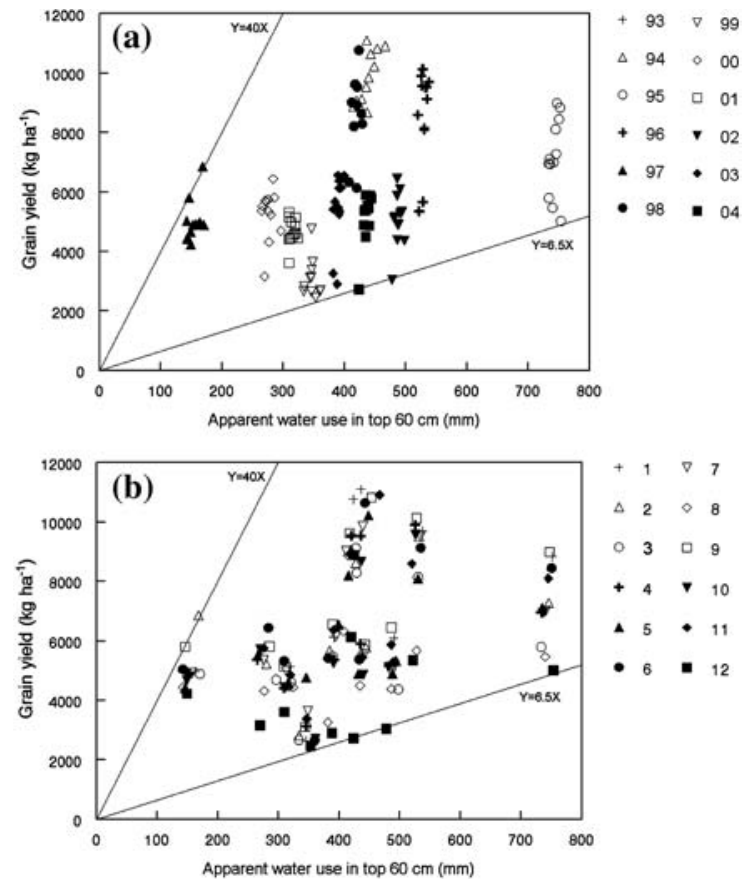

Fig. 4 Relationships between grain yield and apparent water use for all experimental years (a) and treatments (b). The lines $Y=6.5 \mathrm{X}$ and $Y=40 \mathrm{X}$ indicate extreme low and high water use efficiency, respectively, and are meant for comparison. Data from $0 \mathrm{~cm}$ to $60 \mathrm{~cm}$ soil depth

(Fig. 5c, d). For K, PhE ranged from $44 \mathrm{~kg}$ to $60 \mathrm{~kg}$ in 1999 and 2004 to $120-150 \mathrm{~kg}$ in 2003 . On average, treatment 2 ( $\mathrm{f}=105, \mathrm{~s}=3,000, \mathrm{~m}=0 \mathrm{~kg} \mathrm{ha}^{-1}$ ) had the highest $\mathrm{KPhE}$, but patterns were not consistent over years. Also for K, climate had a stronger effect than treatments on PhE (Fig. 5e, f).

Ratios of $\mathrm{P}$ uptake to $\mathrm{N}$ uptake in aboveground biomass ranged from 0.06 to 0.3 (equivalent to N/P ratios of 4 to 16 (Fig. 6)). Ratio of N/P was lowest in 2004 and highest in 2002. There were no clear and consistent patterns in N/P ratios between treatments. Ratios of $\mathrm{K}$ uptake to $\mathrm{N}$ uptake in aboveground biomass ranged from 0.3 to 1.0 (equivalent to $\mathrm{N} / \mathrm{K}$ ratios of 1 to 3.6). Ratio of N/K was lowest in 2004 and highest in 2000. There were no clear and consistent patterns in $\mathrm{N} / \mathrm{K}$ ratios between treatments (Fig. 6).

Apparent $\mathrm{N}$ recovery efficiency (NRE) was related to added manure and fertilizer (linear and quadratic effects, respectively) and to rainfall in July and August to October, but the percentage variance accounted for was small (Table 3). The same holds for PRE (data not shown). Mean NRE ranged from about $25 \%$ in the dry years 1997 and 1999 to $70-80 \%$ in the wet years 1996 and 1998. Mean PRE ranged from about $15 \%$ in the dry years 1997 and 1999 to 30-40\% in the wet year 1996 and 1998. Splitting the data set in dry and wet years (see above) resulted in a much higher percentage variance accounted for, and showed statistically significant effects of fertilizer and manure in dry years, and of fertilizer and stover in wet years (not shown). Also, there were statistically significant effects of fertilizer and manure on PRE in both dry and wet years. In addition, there was a statistically significant interaction between NP fertilizer and manure in both dry and wet years (not shown).

\section{Discussion and conclusions}

Grain yields of spring maize in drylands of northern China were greatly influenced by SWS and GSR. Differences between years in mean GY were in the order of 200-300\% (e.g. between 1994 and 2004), and these differences were mainly related to SWS and GSR. In addition, GY was limited by the availability of nutrients, especially $\mathrm{N}$, but likely also $\mathrm{P}$ and $\mathrm{K}$. Added NP fertilizer, maize stover and cattle manure increased GY and $\mathrm{N}, \mathrm{P}$ and $\mathrm{K}$ uptake in aboveground biomass, but effects of maize stover and cattle manure were not statistically significant in all years. Balanced combination of NP fertilizer, maize stover and cattle manure gave the highest yield. Averaged over the 12-year experimental period, a balanced combination of NP fertilizer, maize stover and cattle manure (treatment 9) increased GY by $60 \%$ relative to the control treatment. Clearly, fertilization effects were smaller than rainfall effects.

The difference in GY between the control treatment and the treatments with balanced combinations of NP fertilizer, stover and manure tended to increase over time, mainly because GY of the control treatment declined during the experimental period, due to nutrient depletion of the soil. Yields of other treatments also tended to decline during the experimental period, but this decline could be ascribed to changes in the amounts and distribution of rainfall over the growing season (Table 3, Fig. 3). Grain yields in some years may also have been affected by diseases (mainly head smut). Decreasing GSR, soil 

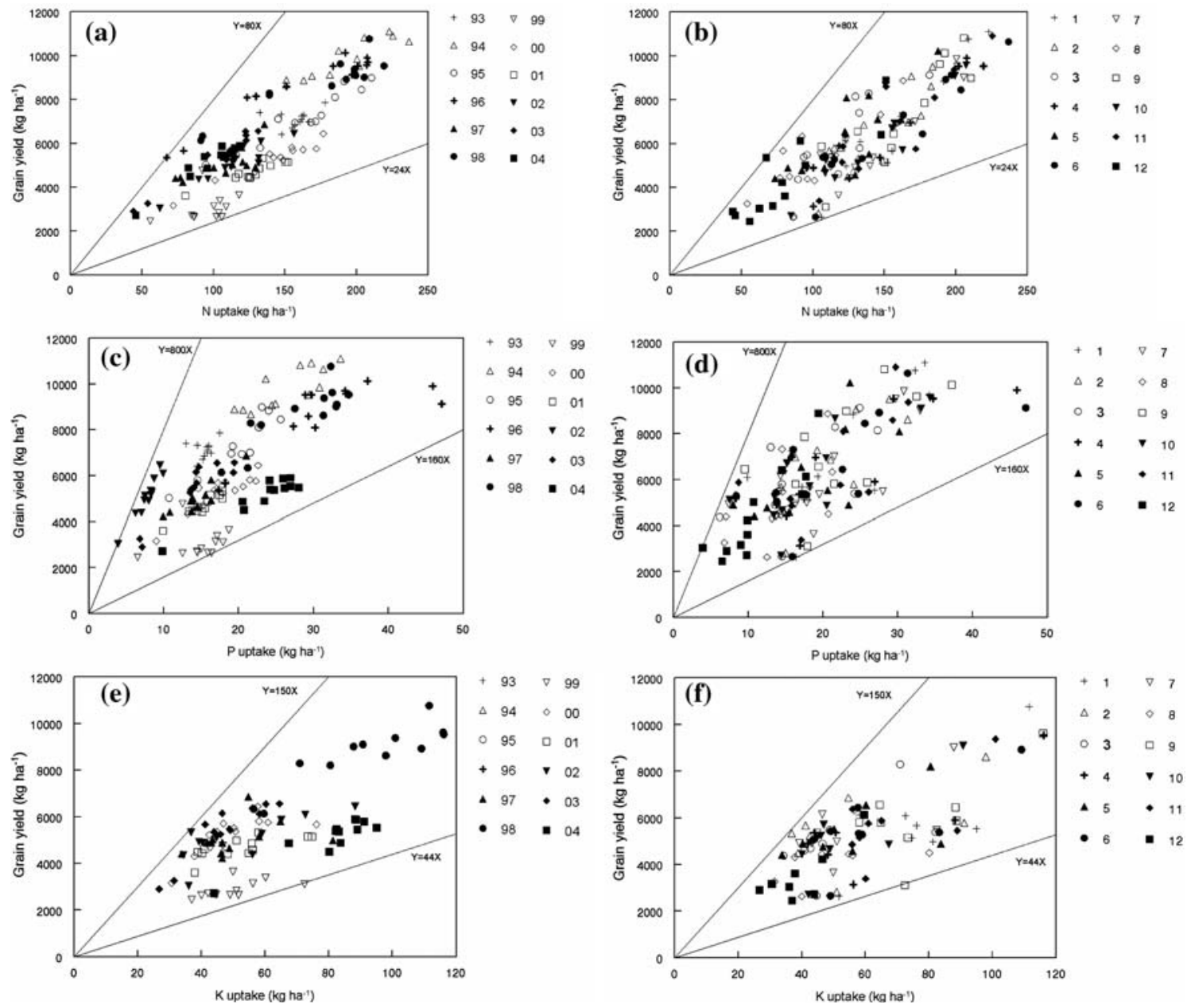

Fig. 5 Relationships between grain yield and $\mathrm{N}$ uptake for all experimental years (a) and treatments (b). Relationships between grain yield and $\mathrm{P}$ uptake for all experimental years (c) and treatments (d). Relationships between grain yield and $\mathrm{K}$ uptake for all experimental years (e) and treatments (f). The

nutrient depletion and diseases have been identified as major causes for declining yields of continuous spring maize cropping systems in northern China ( $\mathrm{Li}$ et al. 2003; Bai et al. 2006).

Water limited grain production

Water use efficiency (WUE) averaged over the 12year period ranged from 1.1 for the control treatment to $1.9 \mathrm{~kg} \mathrm{ha}^{-1} \mathrm{~m}^{-3}$ for treatments with balanced additions of NP fertilizer, stover and manure (Table 2). These values are common for

two lines within each graph approximate maximum dilution (high physiological nutrient use efficiency $(\mathrm{PhE})$; upper line) and maximum accumulation (low physiological nutrient use efficiency; lower line)

non-irrigated maize production and clearly show that balanced fertilization increases the efficiency of water use (Van Keulen and van Laar 1986; Van Keulen and Seligman 1987; Fan et al. 2005a). Differences in WUE were much larger between years than between treatments (Fig. 4). Even at similar apparent water use, there were large differences in GY and hence in WUE. Some of these differences may be attributed to differences in maize variety, as different varieties were used for the periods 1993-1997, 1998 and 1999-2004. A major factor explaining differences in mean WUE between 

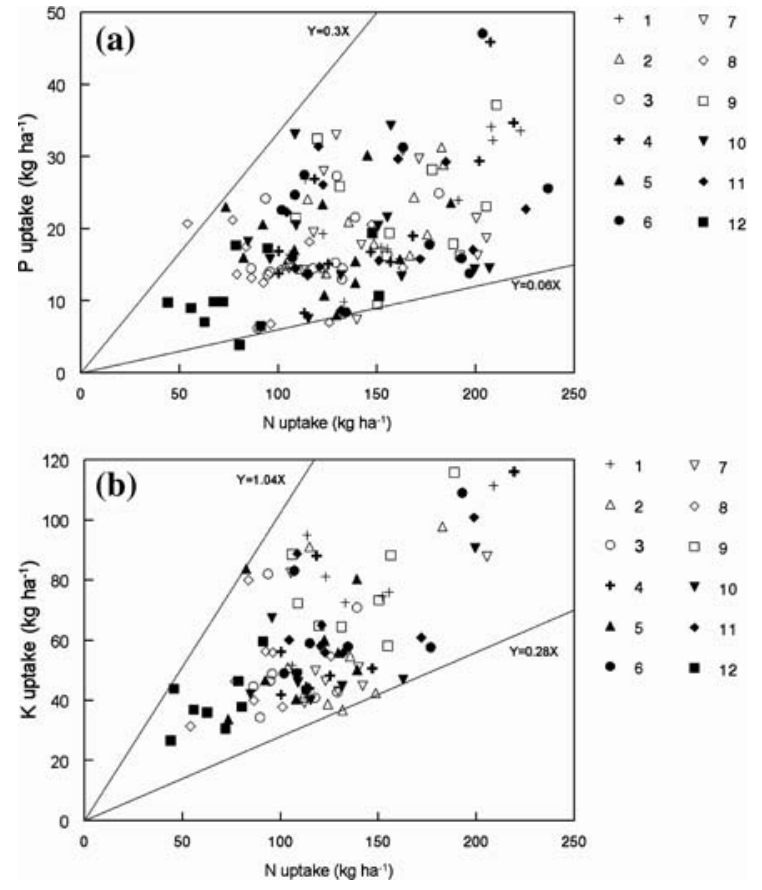

Fig. 6 Relationships between $\mathrm{P}$ uptake and $\mathrm{N}$ uptake (a) and between $\mathrm{K}$ uptake and $\mathrm{N}$ uptake (b) for all treatments. The lines within the graphs indicate extreme high (upper lines) and extreme low (lower lines) ratios of P:N (a) and K:N (b) in the aboveground biomass at harvest

years is the distribution of the rainfall over the growing season. Our results indicate that the amount of soil water at seeding (SWS) and the amount of rainfall during tasseling, commonly in July, are highly critical (Table 3). A third possible factor explaining differences in mean WUE between years is related to $\mathrm{N}$ losses and low $\mathrm{N}$ use efficiency. For example, the low WUE in 2004 (Fig. 4) is accompanied by low N/P and low N/K ratios (Fig. 6) and relatively high $\mathrm{N}$ use efficiency (Fig. 5a, b). This may suggest that $\mathrm{N}$ uptake was low because soil $\mathrm{N}$ was lost prior to or during the growing season. Alternatively, diseases may have (also) played a role. We recall that NP fertilizer, stover and manure were applied in autumn; late season rainfall and rainfall in winter and spring may have contributed to $\mathrm{N}$ losses via leaching and denitrification (Cai et al. 2002; Mosier 2002). Evidently, high SWS is beneficial from the viewpoint of germination and early growth of maize (Cai et al. 1994), but on the other hand may also contribute to $\mathrm{N}$ losses and low $\mathrm{N}$ use efficiency and thereby to low WUE.
Nutrient limited grain production

Balanced combinations of NP fertilizer, stover and manure gave higher GY than additions of NP fertilizer alone, at all levels of NP (Table 2, Fig. 2), suggesting that the effects of manure and especially stover were additional to the effects of NP fertilizer. Results presented in Table 3 and Figs. 2 and 5 show that stover and manure increased $\mathrm{K}$ uptake. Treatments with relatively large applications of NP fertilizers and low application rates of stover and manure had relatively high $\mathrm{N} / \mathrm{K}$ ratio in the aboveground biomass (Fig. 6), indicating unbalanced supply of $\mathrm{N}$ and $\mathrm{K}$. Deficiency of $\mathrm{K}$ was not foreseen at the start of the experiment in 1993, and analyses of $\mathrm{K}$ in biomass only started in 1997 . Our results suggest that 'the stover effect' likely was a ' $K$ effect'. Deficiency of $\mathrm{K}$ in crop production usually appears following increases in NP fertilizer applications and decreases in the use of organic fertilizers (Lin et al. 1999; Ju et al. 2005). Intensification of crop production, in combination with unbalanced fertilization, has already resulted in depletion of $\mathrm{K}$ in soils over large areas in China (Jin et al. 1999), India (Hasan 2002) and other countries in South-East Asia (Ladha et al. 2003; Hoa et al. 2006).

Maize GY responded to $\mathrm{N}$ and $\mathrm{K}$ applications and possibly also to $\mathrm{P}$ application. However, the effects of $\mathrm{N}$ and $\mathrm{P}$ were confounded because $\mathrm{N}$ and $\mathrm{P}$ applications were combined in all treatments. The response to $\mathrm{N}$ also follows from the relatively high $\mathrm{PhE}$ for $\mathrm{N}$ in the control treatment, which ranged from $40 \mathrm{~kg}$ to $80 \mathrm{~kg}$ grain per $\mathrm{kg} \mathrm{N}$ taken up (Fig. 5a, b). The higher value is close to 'maximum dilution', which is indicative for shortage of $\mathrm{N}$ (Janssen et al. 1990; Janssen and de Willigen 2006). For $\mathrm{K}, \mathrm{PhE}$ in the control treatment ranged from $40 \mathrm{~kg}$ to $120 \mathrm{~kg}$ grain per kg K taken up (Fig. 5e, f), and for P, PhE ranged from $160 \mathrm{~kg}$ and $800 \mathrm{~kg}$ grain per $\mathrm{kg} \mathrm{P}$ taken up (Fig. 5c, d). Such wide ranges reflect variations between maximum dilution and maximum accumulation of $\mathrm{K}$ and $\mathrm{P}$ in the aboveground biomass (Janssen et al. 1990). The annual variations in $\mathrm{PhE}$ for $\mathrm{P}$ and $\mathrm{K}$ were related to the distribution of rainfall over the growing season. For both $\mathrm{P}$ and $\mathrm{K}$, differences in $\mathrm{PhE}$ were smaller between treatments than between annual means, suggesting that GSR had much stronger effects on the $\mathrm{K}$ and $\mathrm{P}$ use efficiencies than NP fertilizer, stover and manure. 
Fertilizers, stover and manure were applied in autumn after harvest of the crop, just before ploughing, and about 6 months before seeding. This practice was adopted to reduce wind erosion and soil drying in spring and also to minimize labor requirement (Cai et al. 1994; Wang et al. 2006). The trade-off is that added nutrients are present in the soil for a long time and thus will be more susceptible to losses. Mean apparent $\mathrm{N}$ recoveries (NRE) were in the range of 30-55\%, which are common values for rainfed maize (Balashubramanian et al. 2004; Krupnik et al. 2004), suggesting indeed that $\mathrm{N}$ losses were not excessive. In years with a favorable rainfall distribution, NRE ranged from $50 \%$ to $90 \%$. However, NRE values in treatments with stover and manure were positively affected by addition of $\mathrm{K}$, especially during the second half of the experimental period when GY and $\mathrm{N}$ uptake of the control treatment had declined to relatively low values. We conclude that adding stover and manure in autumn just before ploughing, combined with direct drilling of maize seeds in spring, is a proper way of minimizing wind erosion and labor requirement, while crop yield and $\mathrm{N}$ use efficiency can still be relatively high. The experiment does not allow making a conclusion about the possible superiority of reduced tillage over conventional tillage practices as regards GY and nutrient use efficiencies.

Interactions between NP fertilizer, stover and rainfall in some years may point at temporary immobilization of $\mathrm{N}$ during the decomposition of stover, which has a high $\mathrm{C} / \mathrm{N}$ ratio. Adding stover and $\mathrm{N}$ fertilizer simultaneously may temporary lock up mineral $\mathrm{N}$ in soil organic matter and thereby circumvent its possible loss from soil by leaching and denitrification, and its uptake by plant roots. This temporary immobilization of $\mathrm{N}$ in autumn and its partial mineralization during the growing season may have contributed to positive effects of stover application and also to the positive effects of combined applications of $\mathrm{N}$ fertilizer, stover and manure (Kramer et al. 2002). Split application of $\mathrm{N}$ fertilizer is a well-established management strategy to improve the $\mathrm{N}$ use efficiency of cereal crops (e.g., Schröder et al. 2000; Pattey et al. 2001; Angás et al. 2006). It is recommended to apply about half or two-thirds of the recommended total $\mathrm{N}$ dose at sowing and the supplement after emergence of the crop. The supplemental $\mathrm{N}$ should depend on rainfall conditions and the N status of the soil or crop (Schröder et al. 2000), and in dry years, supplemental $\mathrm{N}$ should not be applied (Angás et al. 2006). When applied under the conditions of Shouyang, the first $\mathrm{N}$ dressing (up to $100 \mathrm{~kg} \mathrm{ha}^{-1}$, depending on stover and manure applications) should be applied after harvest (before ploughing), as in the current experiment. A possible second $\mathrm{N}$ dressing (up to $50 \mathrm{~kg} \mathrm{ha}^{-1}$ ) may be applied at the 4-6 leaves stage, depending on early season rainfall and the $\mathrm{N}$ status of the soil (Schröder et al. 2000; Dobermann and Cassman 2002). The feasibility of such split application technology in practice needs to be tested further. Evidently, split application will increase labor requirement, but can also contribute to further increasing $\mathrm{N}$ use efficiency.

\section{Conclusions}

Traditional Chinese farming was based on efficient utilization and recycling of natural resources. The increasing quest for food by the growing human population led to an increase of $\mathrm{N}$ (and $\mathrm{P}$ ) fertilizer use, unbalanced nutrition and decreasing resource use efficiency. The results of this long-term field experiment show that applications of stover and manure at levels which can be realized on a farm can contribute to increase the use efficiency of $\mathrm{N}$ fertilizer.

Grain yield and N, P and $\mathrm{K}$ use efficiencies of rainfed maize were strongly related to rainfall and to soil water at seeding. The huge annual variations in physiological N, P and $\mathrm{K}$ use efficiencies indicate that there is scope for improvement of fertilizer use efficiency by split application.

The design of this field experiment was meant to provide the most effective and efficient way to balanced fertilization. There were three nutrient sources (NP fertilizer, stover and manure), each applied at five rates, and these were combined in an incomplete factorial design of 12 treatments only. The statistical model pertinent to the design was able to describe the mean responses of NP fertilizer, stover and manure reasonably well. This design has proven to be efficient for experiments with nutrient inputs. However, nutrient management under rainfed conditions requires rainfall to be taken into account in a dynamic approach (see also Wang et al. 2007) to explain the strong interactions between GSR and the effects of NP fertilizer, stover and manure. The feasibility and adoptability by farmers of split applications of $\mathrm{N}$ fertilizer combined with soil and/or plant analyses should be tested in practice. 
Acknowledgments The studies are part of the National Dryland Farming Key Projects of Science and Technical Supporting Programs /the National High-Tech Research and Development Programs of China ("863 Program") for the 8th, 9th, 10th and 11th Five-Year Plans (no.2006AA100220/ 2006AA100220206) and the International Cooperation Project (2006DFB32180) financed by the Ministry of Science and Technology of China, and co- financed by China Scholarship Council, the National Natural Science Foundation of China (no. 40571151), the State Key Laboratory of Soil and Sustainable Agriculture at Chinese Academy of Sciences, and Beijing key lab of Resources Environment and GIS at Capital Normal University. This paper was accomplished in cooperation with the Department of Soil Quality, and Farm Technology Group at Wageningen University.

\section{References}

Angás P, Lampurlanés J, Cantero-Martínez C (2006) Tillage and $\mathrm{N}$ fertilization effects on $\mathrm{N}$ dynamics and barley yield under semiarid Mediterranean conditions. Soil Tillage Res 87:59-71

Bai YX, Chen BG, Zhang RS, Lu GH, Zheng LS, Li LY (2006) Analysis of present situation and integrated control of head smut in spring corn area of North of Shanxi. J. Shanxi Agric Sci 34(1):65-67 (in Chinese)

Balashubramanian V, Alves B, Aulakh M, Bekunda M, Cai Z, Dringwater L, Mugendi D, van Kessel C, Oenema O (2004) Crop, environmental, and management factors affecting nitrogen use efficiency. In: Mosier AR, Syers JK, Freney JR (eds) Agriculture and the nitrogen cycle. SCOPE 65. Island Press, Washington, pp 19-33

Bao X, Watanabe M, Wang QX, Hayashi S, Liu JY (2006) Nitrogen budgets of agricultural fields of the Changjiang River basin from 1980 to 1990. Sci Total Environ 363:136-148

Cai DX, Gao XK, Zhang ZT, Wang XB (1994) Effects of presowing tillage measures on soil moisture retention and seedling emergence of spring crops. Soils Fert 2:10-13 (in Chinese)

Cai GX, Chen DL, Ding H, Pacholski A, Fan XH, Zhu ZL (2002) Nitrogen losses from fertilizers applied to maize, wheat and rice in the North China Plain. Nutr Cycl Agroecosyst 63:187-195

Cao ZH (1996) Environmental issues related to chemical fertilizer use in China. Pedosphere 6(4):289-303

China Agricultural Yearbook (1999) Agriculture Press, Beijing (in Chinese)

Dobermann A, Cassman KG (2002) Plant nutrient management for enhanced productivity in intensive grain production systems of the United States and Asia. Plant Soil 247:153-175

Fan TL, Stewart BA, Yong W, Luo JJ, Zhou GY (2005a) Long-term fertilization effects on grain yield, water-use efficiency and soil fertility in the dryland of Loess Plateau in China. Agric Ecosyst Environ 106:313-329

Fan TL, Wang SY, Tang XM, Luo JJ, Stewart BA, Gao YF (2005b) Grain yield and water use in a long-term fertil- ization trial in Northwest China. Agric Water Manage 76:36-52

FAO, Food and Agricultural Organization of the United Nations (2005) FAO Statistical Yearbook 2004, vol 1. Roma, Italy, 364 pp

Hasan R (2002) Potassium status of soils in India. Better Crops Int 16(2):3-5

Hoa NM, Janssen BH, Oenema O, Dobermann A (2006) Comparison of partial and complete soil $\mathrm{K}$ budgets under intensive rice cropping in the Mekong Delta, Vietnam. Agric Ecosyst Environ 116:121-131

ISS-CAS, Institute of Soil Science, Chinese Academy of Science (2003) Scientific data base. China soil data base, http://www.soil.csdb.cn/ Last Updated: March, 2003. Institute of Soil Science, CAS, China

IUSS Working Group WRB (2006) World reference base for soil resources 2006. A framework for international classification, correlation and communication, 2nd edn. World Soil Resources Reports No. 103. FAO, Rome

Janssen BH, de Willigen P (2006) Ideal and saturated soil fertility as bench marks in nutrient management: II. Interpretation of chemical soil tests in relation to ideal and saturated soil fertility. Agric Ecosyst Environ 116:147-155

Janssen BH, Guiking FCT, van der Eijk D, Smaling EMA, Wolf J, van Reuler H (1990) A system for quantitative evaluation of the fertility of tropical soils (QUEFTS). Geoderma 46:299-318

Jin JY, Lin B, Zhang W (1999) Improving nutrient management for sustainable development of agriculture in China. In: Smaling EMA, Oenema O, Fresco LO (eds) Nutrient disequilibria in agroecosystems: concepts and case studies. CABI Publishing, Wallingford, UK, pp 157-174

Ju XT, Zhang FS, Bao XM, Romheld V, Roelcke M (2005) Utilization and management of organic wastes in Chinese agriculture: past, present and perspectives. Sci China C Life Sci 48:965-979

Ju XT, Kou CL, Zhang FS, Christie P (2006) Nitrogen balance and groundwater nitrate contamination: comparison among three intensive cropping systems on the North China Plain. Environ Pollut 143:117-125

Khuri AI, Cornell JA (1987) Response surfaces: designs and analyses. Statistics: textbooks and monographs 81. Marcel Dekker, New York, pp 105-148

Kramer AW, Doane TA, Horwath WR, van Kessel C (2002) Combining fertilizer and organic inputs to synchronize $\mathrm{N}$ supply in alternative cropping systems in California. Agric Ecosyst Environ 91:233-243

Krupnik TJ, Six J, Ladha JK, Paine MJ, van Kessel C (2004) An assessment of fertilizer nitrogen recovery efficiency by grain crops. In: Mosier AR, Syers JK, Freney JR (eds) Agriculture and the nitrogen cycle, the scientific committee on problems of the environment (SCOPE). Island Press, Covelo, California, USA, pp 193-207

Ladha JK, Dawe D, Pathak H, Padre AT, Yadav RL, Singh B, Singh Y, Singh Y, Singh P, Kundu AL, Sakal R, Regmi AP, Gami SK, Bhandari AL, Amin R, Yadav CR, Bhattarai EM, Das S, Aggarwal HP, Gupta RK, Hobbs PR (2003) How extensive are yield declines in long-term rice-wheat experiments in Asia? Field Crops Res 81: $159-180$ 
Li ZQ, Song DZ, Li JZ, Sun WR, Li QX (2003) Infection cause and control of maize head smut. J Shanxi Agric Sci 31(3):70-72 (in Chinese)

Lin B, Lin JX (1985) A located experiment on the combined application of organic manure and chemical fertilizer. Chinese J Soil Fert 5:22-27 (in Chinese)

Lin B, Li JK, Jin JY (1999) Outlook on fertilizer use in China in next century. In: Research progress in plant protection and plant nutrition. CAAM, China Agriculture Press, pp 345-351

Liu XL, Gao Z, Liu CS (1996) Effect of combined application of organic manure and fertilizer on crop yield and soil fertility in a located experiment. Acta Pedologica Sinica 33:138-147 (in Chinese)

Moll RH, Kamprath EJ, Jackson WA (1982) Analysis and interpretation of factors which contribute to efficiency of nitrogen utilization. Agron J 74:562-564

Mosier AR (2002) Environmental challenges associated with needed increases in global nitrogen fixation. Nutr Cycl Agroecosyst 63:101-116

Novoa R, Loomis RS (1981) Nitrogen and plant production. Plant Soil 58:177-204

Pattey E, Strachan IB, Boisvert JB, Desjardins RL, McLaughlin NB (2001) Detecting effects of nitrogen rate and weather on corn growth using micrometeorological and hyperspectral reflectance measurements. Agric For Meteorol 108:85-99

Peng SB, Buresh RJ, Huang JL, Yang JC, Zou YB, Zhong XH, Wang GH, Zhang FS (2006) Strategies for overcoming low agronomic nitrogen use efficiency in irrigated rice systems in China. Field Crops Res 96:37-47

Rees RM, Roelcke M, Li SX, Wang XQ, Li SQ, Stockdale EA, McTaggart IP, Smith KA, Richter J (1997) The effect of fertilizer placement on nitrogen uptake and yield of wheat and maize in Chinese loess soils. Nutr Cycl Agroecosyst 47:81-91

Roquemore KG (1976) Hybrid designs for quadratic response surfaces. Technometrics 18:419-423

SAS Institute Inc (2004) SAS $^{\mathbb{R}}$ 9.1.2 Qualification Tools User's Guide. SAS Institute Inc, Cary, NC

Schröder JJ, Neeteson JJ, Oenema O, Struik PC (2000) Does the crop or the soil indicate how to save nitrogen in maize production? Reviewing the state of the art. Field Crops Res 66:151-164

Van Keulen H, Seligman NG (1987) Simulation of water use, nitrogen nutrition, and growth of a spring wheat crop. Pudoc, Wageningen, $310 \mathrm{pp}$
Van Keulen H, van Laar HH (1986) The relation between water use and crop production. In: van Keulen H, Wolf J (eds) Modelling of agricultural production: weather, soils and crops. Pudoc, Wageningen, pp 130-152

Wang XB, Cai DX, Zhang JQ (1999) Study on the optimized pattern of agro-husbandry resource in Shouyang dryland farming area. J Agrotech Econ 4:40-43 (in Chinese)

Wang XB, Cai DX, Zhang JQ, Gao XK (2001) Effect of corn stover incorporated in dry farmland on soil fertility. Chin Agric Sci 1:95-101

Wang XB, Cai DX, Zhang JQ, Gao XK (2003) Nitrogen uptake by corn and $\mathrm{N}$ recovery in grain in dry farmland. Chin Agric Sci 2(8):898-905

Wang XB, Oenema O, Hoogmoed WB, Perdok UD, Cai DX (2006) Dust storm erosion and its impact on soil carbon and nitrogen losses in northern China. Catena 66: $221-227$

Wang XB, Hoogmoed WB, Cai DX, Perdok UD, Oenema O (2007) Crop residue, manure and fertilizer in dryland maize under reduced tillage in northern China: II Nutrient balances and soil fertility. Nutr Cycl Agroecosyst doi: 10.1007./s10705-006-9070-6

Westerman RL (ed) (1990) Soil testing and plant analysis, 3rd edn. SSSA Book Ser. 3. SSSA, Madison, WI

Xie CT, Yan HJ, Xu JX (1987) The effect of organic manure on improvement of alkali-saline soil. Chin J Soil Sci 18:97-99

Xu ZR (ed) (1988) The optimum regression designs in agricultural experiments. Heilongjiang Science and Technology Press, pp 216-238 (in Chinese)

Yang HS (2006) Resource management, soil fertility and sustainable crop production: experiences of China. Agric Ecosyst Environ 116:27-33

Yang SM, Li FM, Malhi SS, Wang P, Suo DR, Wang JG (2004) Long-term fertilization effects on crop yield and nitrate nitrogen accumulation in soil in northwestern China. Agron J 96:1039-1049

Ye QL, Rozelle S (1994) Fertilizer demand in China's reforming economy. Can J Agric Econ 42:191-207

Zhen L, Zoebisch MA, Chen GB, Feng ZM, 2006. Sustainability of farmers' soil fertility management practices: a case study in the North China Plain. J Environ Manage 79:409-419 (in Chinese) 